\title{
Historein
}

Vol $10(2010)$

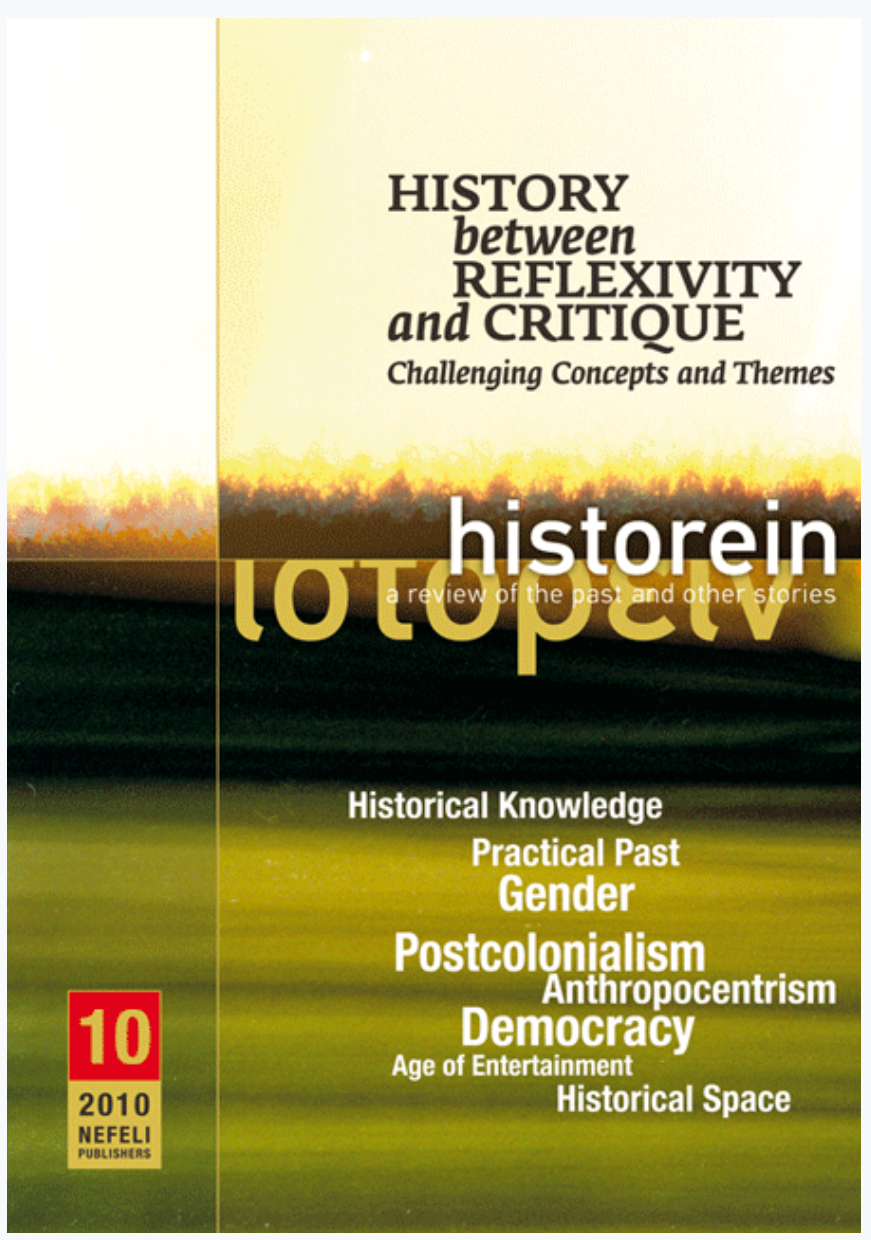

\section{History between Reflexivity and Critique}

Effi Gazi

doi: $10.12681 /$ historein.1

and CRITIQUE

doi. $10.12681 /$ historein.1

\section{Copyright @ 2012, Effi Gazi}

\section{@) $\mathbb{D Q}(\mathbb{0})$}

This work is licensed under a Creative Commons Attribution-NonCommercialShareAlike 4.0.

\section{To cite this article:}

Gazi, E. (2011). History between Reflexivity and Critique. Historein, 10, 5-9. https://doi.org/10.12681/historein.1 


\section{History between Reflexivity and Critique}

"Critique is uncomfortable," the historian Joan W. Scott claims in a recent essay, before she goes on to unravel the disturbances of scrutinising the taken-for-granted as well as the "shock of the new" that critique causes. "Critique uses the language of desire," she also points out, before turning her attention to the motivation and passion which underlie and define critique. ' Feeling "uncomfortable" and having "desires" both played a role in choosing to host an international conference on the topic of "History between Reflexivity and Critique", jointly organised by Historein, the Historical Archive of the University of Athens, the International Commission for Theory and History of Historiography and the European Doctorate in Social History, which took place in Athens from 30 October-1 November 2008. Our scope was exploratory: we brought together scholars from different areas of specialisation and from different perspectives in order to discuss a variety of themes, including: "Reflexive Historiography in East and West",

\section{Introduction}

"A History of Criti-

cal History", "History, Philosophy and Science", "Critique and Modernity”, "Transcultural History", "Postcolonialism as Critique”, "Critical Concepts", and "History and the Politics of Recognition". We aimed at raising anew and at reassessing the themes that have been discussed in the last few decades within the various "post" agendas. We also meant to move backwards and forwards; we wanted to explore the concepts of critique and reflexivity in the long term, to examine their functioning in different settings, to investigate the ways they have been shaped and reshaped, as well as to try to anticipate future orientations in history. By placing history between reflexivity and critique, we turned our attention to the question of what history will become, bearing in mind that historical knowledge is being repositioned within the contemporary configurations of the so called 
"knowledge economy". It was from this perspective that we proceeded to the publication of selected papers in the present volume.

This has been a difficult task, indeed. Drawing on Michael Oakshott's concept of the "practical past", Hayden White argues, in the first chapter of the volume, that "coming to terms with the past" today means to reflect on the kind of knowledge produced about the past. In this vein, he explores how the "practical past" was thrown out of the window of the proper historical discipline. The more "scientific" history became, according to White, the more it was removed from "practical reason". By defining the past as "a space of experience", White emphasises the importance of relating it to the present through innovative ways that might converge, such as, for instance, historiographical metafiction or the postmodernist "neohistorical novel". The kind of knowledge produced about the past that White explores has also been at the centre of historians' interest in other historical moments. In fact, it stands at the centre of historiographical criticism. A detachment from religion, a reconsideration of religious-historical narratives and a turn to the secular have played a crucial part in this respect. Costas Gaganakis discusses how Lancelot Voisin de la Popelinière's interest in the critical interpretation of evidence and in an all-inclusive history aimed at emancipating the study of the past from theology. Gaganakis places the "historical revolution" of the sixteenth century in the context of the cataclysmic events unleashed by the wars of religion between Catholics and Protestants. In this context, history rose as a hermeneutic endeavour while it became related to earlier processes of nationalisation in the European sixteenth century. The study of history as an answer to a set of existential questions stands at the centre of J. D. Braw's contribution on Ranke's work. Braw relates Rankean criticism to an attempt to transfer religious concerns and beliefs into the secular context and to unravel conceptualisations of vocation so that the past unfolds into the present and the future. Servanne Jollivet, on the other hand, discusses how philosophy and history came together against theology. By focusing on Dilthey, Troeltsch and Heidegger, Jollivet turns her attention to a critical philosophy of history which implements both philosophical perspectives and historicist paradigms in order to formulate its critical arguments. In this vein, she revisits major issues of historical reflexivity claimed by philosophers from the late nineteenth century onwards vis à vis historical writing, relativism and metaphysics.

Gaganakis, Braw and Jollivet remind us, in the most illustrious manner, that historiography as a field has been constituted on the very processes of reflexivity and critique. Both concepts are familiar to relevant scholarship. Yet, familiarity does not presuppose homogeneity or linearity in processes. Neither has it contributed to the rise of a uniform agenda on the politics of reflexivity and critique. On the contrary, the hot and tense debates that have marked history in the last decades vis à vis, for instance, the concepts of "science" or of "society" or "the past", either in its "real", "practical" or "imaginary" configurations, point towards desirable, yet rather uncomfortable and at times painful, processes of reflexivity and critique.

This is even more so because of the inherent tensions in reflexive and critical history. Let us make a special reference to these inherent tensions. Firstly, by being object dependent, both reflexivity and critique are shaped and formed by their emphasis on particular themes, for instance on gender or on the colonial. Reflexivity and critique are relational in the sense they ex- 
ist in relation to something other than themselves in an attempt to question "given truths". ${ }^{2}$ In recent historical scholarship, critical perspectives on imperialist and colonial narratives not only enriched our knowledge of the practices that surround history-writing but also led to a new understanding of power. ${ }^{3}$ Pothiti Hantzaroula shows how gender has called into critical examination the foundations of the historical discipline and how historical knowledge has been grasped by feminist historical writing. Gendering the historical narrative has opened, as Hantzaroula argues, a variety of new conceptualisations and themes in history. Sanjay Seth examines, in his contribution, how the rise of the history of the "collective singular", that is, of Man, in premodern Europe as well as the formation of the "sciences of Man" imposed a code of conceptualising the past even for those who did not live by that code such as the non-West. By pointing at the crucial question of the foundations of western historical thinking, Seth raises the important issue of its reassessment. Yet, this condition of object dependency does not exclude either the process of generating new objects or the process of invoking alterations in the wider historical field, irrespective of their own particularity. Edward Wang enriches our knowledge of the intellectual and political formation of postcolonial historians, especially the core group of the Subaltern Studies project, by turning his attention to the Maoist underpinnings of their Marxism, to their initial interest in the Cultural Revolution and to their study of the Chinese historiography on peasants. Wang defines postcolonial scholarship as paradoxical in nature since it is an offshoot of cultural developments in the West and a persistent attempt to engage in a criticism of them. Through his critique of the subalternists' approach to nationalism, Wang turns our attention to the important theme of colonialism and nationalism as well as to the issue of the impact of contemporary nationalism. Secondly, amorphous as it may be, critique acts as a transformative power. Reflexive and critical interventions impose their transformative power on history, even if they are not complete or even when they are controversial. It is necessary, however, to elaborate and clarify the concepts of reflexivity and critique within particular and distinct historical agendas and topics. Diana Mishkova turns her attention to the transformative power of critique by pointing to the ways "scale shifts", that is, shifts in the scale of observation of historical reality, offer a view into differentiated "spaces of experience". In this context, she elaborately examines the critical historical scholarship on the Balkans in the 1930s which opened up new perspectives on the history of the region. For Mishkova, that historical perspective which implemented regional "challenges" formed an important critique of nation-centred history. Finally, reflexivity and critique in their philosophical, epistemological and ethical underpinnings have definitely contributed to the ramifications of historical thought; yet, historical critique is also placed within history. It is formed and determined by particular historical contexts while it functions within its own historicity. It is historically bound. This becomes evident in the interactive dialogue between history and contemporary critical theory which has opened up space for new experimental narratives. ${ }^{4}$ In this vein, Kalle Pihlainen investigates the role and function of history in the "entertainment age". By focusing on contemporary evolutions especially in the field of new media, Pihlainen looks for new critical attitudes beyond traditional professional practices in history, urging for a conceptualisation of history as communication rather than interpretation. Ewa Domanska, on the other hand, relates the necessity for reflexivity and critique to current concerns about the kind of humanities we need today. She discusses the rise of a new interest in the "nonhuman" as well as the critique of traditional anthropocentrism and defines nonanthropocentric humanities as posthumanities. By turning her attention to an emerging paradigm inspired by biology and technosci- 
ence, she argues for a nonanthropocentric history as well as for a posthumanist displacement of our interpretive frameworks in history.

The interest in the historicity of reflexivity and critique has further implications. As mentioned above, while we opted for this particular topic both for the conference and for the present volume, we had an eye on the future of the past. We also aimed at turning our attention to that history which is not necessarily or exclusively about the past. For decades now, historians have worked against a backdrop of questions around the nature of their discipline. At times, this backdrop has produced such tensions that seemed to be in conflict with their work. Indeed, very few topics remained uncontested in the course of embattled processes of critique and reflexivity. What's next? We thought that by posing history "in between" reflexivity and critique, we could perhaps come up with a different suggestion. We aimed at moving beyond binary oppositions. After all, critique is not just about "fault finding". It is a practice that suspends judgment and activates modes of questioning. ${ }^{5}$ It is also a form of resistance to what is taken for granted. Yet, one question remains puzzling. There is a form of historical critique or of "history-writing as critique" or of critical history that demands further attention. It is that form which has allies and adversaries, friends and opponents, that one which carries the power of political energy. What is the future of critical history now that earlier forms of it are either institutionalised or domesticated or even routinised while politics itself is changing dramatically? Some decades ago, Reinhart Koselleck explored how the split between the absolutist state and society contributed to the emergence of new forms of critique and produced new models for political society within the confines of the Enlightenment. ${ }^{6}$ Moments of tension and turbulence invite processes of critique around new agendas. Could this apply to contemporary history? Alexandra Lianeri recasts the burning issue of an emancipatory political critique through the intellectual history of democracy. Drawing on Foucauldian notions of critique and governmentability, Lianeri explores an intellectual and political tradition which focuses on the Athenian democracy and the Roman republic in an attempt to illustrate how the Roman (republican) appropriations of the Greek concept of democracy offered the founding moment of humanism and the politics of the modern democratic state. A radical vision of democracy arises from underneath the layers of age-old appropriations and reconceptualisations. Lianeri discusses this vision vis à vis the contemporary crisis of democracy. In his concluding essay, Antonis Liakos reflects on the ways of doing critical history today. By juxtaposing conceptualisations of "critical history" in the 1960s and 1970s with current perceptions, he explores the concept of critique, drawing on the Foucauldian analysis of systems of thought and forms of governmentability. In this line of argumentation, he argues for a critical history that avoids self-referentiality and efficiently establishes itself within contemporary forms and communications media.

Two different but paradoxically complementary contributions are included in the "Interventions" section. Daho Djerbal proposes a research project which aims at bringing together the history of a colonial and postcolonial society and of a colonial power. By focusing on Algeria (and, as a consequence, on France), he reflects on the study of elites and of political conceptualisations in an attempt to explore the ways the colonial system produced new social agents and to revisit the history of colonialism in general. Finally, Athena Athanasiou and Elena Tzelepis discuss with Julia Kristeva. By turning into Simon de Beauvoir's leftist feminist vision, Kristeva combines po- 
litical philosophy, psychoanalysis and literature in a critical investigation of the theme of freedom. By defining it as "the power to constantly transcend", Kristeva argues for the intellectual and political importance of "continually moving beyond".

The present volume aims especially at "moving beyond" through the processes of reflexivity and critique. Let us view it as an open invitation to the pleasures and anxieties, to the threats and desires that reflexivity and critique can generate in their disturbing, annoying, painstaking, yet exciting call on history and, especially, on historians.

Effi Gazi

\section{NOTES}

1 Joan W. Scott, "History-writing as Critique", in Keith Jenkins, Sue Morgan and Alun Munslow (eds), Manifestos for History, London: Routledge, 2007, 19-38.

2 Michel Foucault, The Politics of Truth, ed. Sylvère Lotringer and Lysa Hochroth, New York: Semiotext(e), 1997, 25, 32.

3 Dipesh Chakrabarty, "History as Critique and Critique(s) of History", Economic and Political Weekly, 14 September 1991, 2162-66.

4 See in particular Dominick La Capra, History in Transit: Experience, Identity, Critical Theory, Ithaca and London: Cornell UP, 2004.

5 Judith Butler, "What is Critique? An Essay on Foucault's Virtue", in Sara Salih with Judith Butler (eds), The Judith Butler Reader, Oxford: Blackwell, 2003, 302-22.

6 Reinhart Koselleck, Critique and Crisis: Enlightenment and the Pathogenesis of Modern Society, Cambridge, MIT Press, 1988. 